Journal of Advanced Research in Fluid Mechanics and Thermal Sciences

Journal homepage: www.akademiabaru.com/arfmts.html ISSN: 2289-7879

\title{
Feasibility Analysis of a Pico-Scale Turgo Turbine Bucket using Coconut Shell Spoons for Electricity Generation in Remote Areas in Indonesia
}

\author{
Dendy Adanta ${ }^{2}$, Warjito ${ }^{1,}{ }^{*}$, Dwijaya Febriansyah ${ }^{1}$, Budiarso $^{1}$ \\ Department of Mechanical Engineering, Faculty of Engineering, Universitas Indonesia, Depok 16424, West Java, Indonesia \\ Department of Mechanical Engineering, Faculty of Engineering, Universitas Sriwijaya, Indralaya 30662, South Sumatera, Indonesia
}

\section{ARTICLE INFO}

\section{Article history:}

Received 11 December 2019

Received in revised form 29 January 2020

Accepted 29 January 2020

Available online 7 April 2020
Keywords:

Pico hydro; Turgo turbine; bucket;

electricity; remote area

\section{ABSTRACT}

Until 2018, 1396 villages in Indonesia, deemed as remote areas, still did not have access to the national grid electricity. To resolve this issue, the use of independent power plants is an appropriate solution. The use of a pico-scale Turgo turbine, which is an independent power plant, is recommended in Indonesia due to its mini-, micro-, and pico-scale water energy potential of $19 \mathrm{GW}$. As the Turgo turbine is intended for use in remote areas, the use of local materials, e.g., coconut shells, is proposed as the bucket material. From static compressive strength tests revealed that the maximum pressure points a coconut shell proportional to the water pressure with a potential power of $3300 \mathrm{~W}$. The size of a coconut shell spoon, which is not uniform, can be overcome by its curvature angle. The curvature angle represents the relative angle of the incoming and outgoing jets, while this is a represents of the depth and length of the spoon. Thus, to ensure the performance of the Turgo turbine under maximum conditions, the curvature angle of the coconut shell spoon is $\sim 90^{\circ}$. Moreover, the total efficiency of the turbine is $34.94 \%$, with a possibility of reaching higher values.

Copyright $@ 2020$ PENERBIT AKADEMIA BARU - All rights reserved

\section{Introduction}

Until 2018, 1396 villages, corresponding to $1.7 \%$ of the total number of villages, in Indonesia still did not have access to electricity [1], where a majority of these villages are located in remote areas. Generally, the remote areas in Indonesia are hilly regions, which still do not have adequate access to the infrastructure, leading to the difficult in expanding the electricity grid. In addition, the high costs associated with the expansion of the electricity grid to remote areas are a limitation. The electricity grid expansion is expensive because it is difficult to obtain licenses to open up land for expansion electricity grid in protected forest areas or nature reserves and to provide compensation

\footnotetext{
* Corresponding author.

E-mail address: warjito@eng.ui.ac.id (Warjito)
}

https://doi.org/10.37934/arfmts.69.1.8597 
commensurate to the loss experienced by those affected by grid expansion. Furthermore, each remote location comprises a small number of residents (implying low electricity utilization), and their income is less than those of urban communities, also leading to unecomonic electricity costs during grid expansion [2]. Thus, independent electricity plants constitute a technological solution to satisfy the needs of electricity in remote areas $[3,4]$. Pico hydro is an independent electricity plant that may be appropriate for remote areas in Indonesia due to its small-, micro-, and pico-scale water energy potential of up to $19 \mathrm{GW}$ under low head conditions $(<5 \mathrm{~m})$ [5].

It is a hydroelectric power plant with a capacity of less than $5 \mathrm{~kW}$ [6]. In terms of investment and operational costs (life-cycle costs), pico hydro is more cost-effective than wind turbines and solar photovoltaics [7,8]. This has been demonstrated in Cameroon [7], Kenya [9], Nepal [10], Laos [11], Rwanda [12], Honduras [13], and Peru [14], which have used pico hydro for the generation of electricity in remote areas.

Typically, under low head conditions, the maximum efficiency is only achieved if reaction turbines such as a propeller, Archimedes, overshot, and undershot are utilized [15]. The use of an impulse turbine (Turgo and/or Pelton turbine) under low head conditions is not favourable, and it is not recommended for pico-scale applications. However, hydropower on the micro, small, mini, and large scale is typically used for commercial purposes; hence, it is crucial to select an appropriate, efficient turbine. While, the case for the use of pico hydro wherein the selection of the turbine is considered in accordance to several factors: maintenance, operational, modularity, portability and investment cost [8]. Based on the assessment by multi-criteria analysis, an impulse-type pico-scale Turgo turbine is recommended for applications in remote areas [15]. Turgo turbines are suitable in remote areas due to their low investment costs, portable, easy to operate and easy maintenance $[15,16]$.

Since the Turgo turbine is an impulse-type turbine, the low rotation velocity produced under low head conditions is an issue [17]. Therefore, a direct current (DC)-type generator is used because it can produce electricity under low rotations [18]; it is cost-effective, and it exhibits a capacity of less than $2 \mathrm{~kW}$ [19]. In addition, several electrical appliances, such as lighting lamps, use DC currents. Moreover, by using electrical equipment with an alternating current $(A C)$, the generated $D C$ current can be stored using batteries and supplied to the AC electrical equipment using an inverter [20].

The performance of the Turgo turbine is affected by its bucket shape because the conversion of water energy to the turbine occurs in a bucket [21]. The bucket shape of the Turgo turbine is curved. The curvature of the Turgo turbine bucket is designed to deflect the flow of water [21]. To achieve the maximum efficiency of a Turgo turbine, a bucket with a flow deflection curve must be manufactured with high precision. However, it is difficult and expensive to make a bucket with good flow deflection [22]. Considering that pico hydro is an independent power plant owned by a person or a group of people, a simple shape as well as construction, low investment and operational costs, as well as maintenance, and easy access to component materials are the main characteristics for the application of a pico-scale Turgo turbine.

The use of materials that are widely available in the market as raw materials for the Turgo turbine buckets has been carried out. For example, stainless-steel spoon materials have been used for making Turgo turbine buckets due to their cost-effective $[16,23]$. Such examples provide new ideas from local Indonesia people for the application of pico hydro. The use of natural raw materials, namely coconut shells, has long been used by the Indonesian people as spoons for eating and cooking. When it comes in contact with water, a coconut shell spoon is strong and durable, although its strength is still less than that of a stainless-steel spoon. Owing to its cost-effectiveness, non-corrosiveness, and abundance throughout Indonesia, coconut shell spoons can be used as the bucket for a Turgo turbine runner. Thus, in this study, the curvature angle of a commercially available coconut shell spoon is 
examined in accordance with the water outlet direction to achieve the maximum efficiency of the turbine.

\section{Theoretical Hydraulic Efficiency of the Turgo Turbine}

The difference between the Turgo turbine and the Pelton turbine is the direction of the jet from the nozzle (Figure 1).

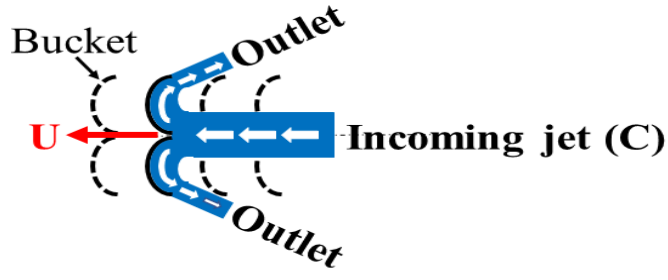

Pelton

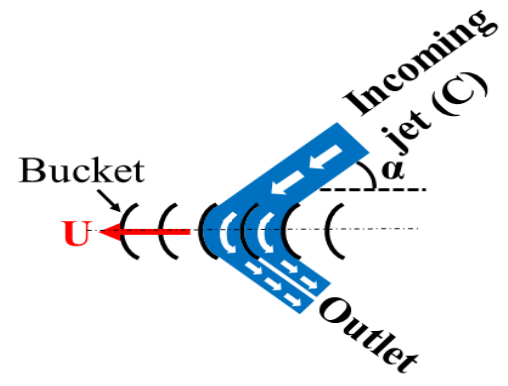

Turgo

Fig. 1. Difference in the angle of the incoming jet of the Pelton and Turgo turbines

The kinetic energy of the water absorbed by the runner is expressed by changes in the inlet and outlet velocities of water (Figure 1 ). The angle of the relative velocity at the water inlet $\left(\beta_{1}\right)$ is made parallel to the edge of the inlet side of the bucket; hence, water can smoothly enter to avoid the occurrence of a hydraulic shock (water hammer) [24]. The calculation of the Turgo turbine design begins by the determination of the actual velocity of the incoming jet or absolute velocity $\left(C_{1}\right)$ based on the head $(H)$ and coefficiency of friciton $\left(C_{d}\right)$ of the nozzle [25] using Eq. (1).

$C_{1}=C_{d} \sqrt{2 g H}$

Generally, the $C_{d}$ value for the Turgo turbine nozzle is 0.96 .

From Figure 2, $C$ is the absolute velocity of water, $W$ is the relative velocity of water, $U$ is the rotation velocity of the wheel, $\beta$ is the angle of the relative velocity, $\alpha$ is the angle of the absolute velocity, 1 is the inlet position, and 2 is the outlet position.

The amount of the absorbed water energy $(E)$ depends on the change in the momentum of the flow of water after passing through the bucket, which is determined using Eq. (2) [26].

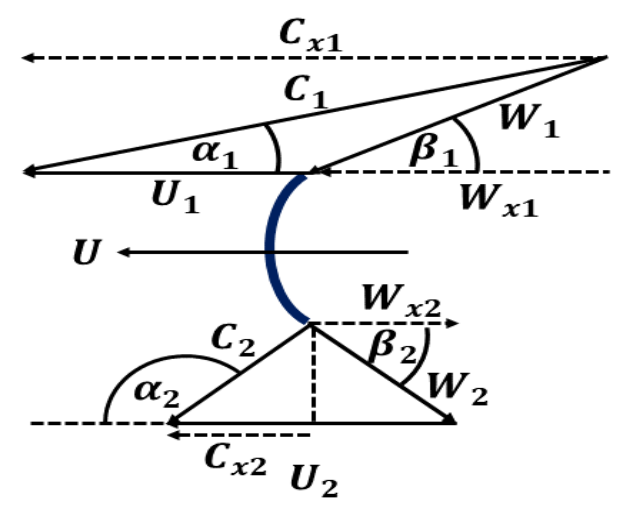

Fig. 2. Vector of velocity triangle in the Turgo turbine [17] 
$E=\frac{\left(U_{1} C_{x 1}-U_{2} C_{x 2}\right)}{g}$

where $C_{x 1}=W_{x 1}+U_{1} ; C_{x 2}=W_{x 2}+U_{2} ; \cos \alpha_{1}=\left(W_{x 1}+U_{1}\right) / C_{1} ; \cos \alpha_{2}=\left(W_{x 2}+U_{2}\right) / C_{2} ; U=$ $r \cdot \omega \cdot \beta_{1}$ can be expressed as follows

$\beta_{1}=\tan ^{-1}\left(\frac{\sin \alpha_{1}}{\cos \alpha_{1}-\varphi}\right)$

where $\varphi$ is the ratio of the rotational velocity of the wheel $(U)$ and the absolute velocity at the inlet $\left(C_{1}\right)$

$\varphi=\frac{U}{C_{1}}=\cos \alpha_{1}-\frac{\sin \alpha_{1}}{\tan \beta_{1}}$

To achieve the maximum efficiency, $\varphi$ is 0.46 [27], while $\alpha_{1}$ varies between $20^{\circ}$ and $40^{\circ}$ [24]. Hence, the power produced by the turbine $\left(P_{M}\right)$ is expressed as follows

$P_{M}=\rho Q\left(U_{1} C_{x 1}-U_{2} C_{x 2}\right)$

Then, the theoretical hydraulic efficiency $\left(\eta_{H}\right)$ is expressed as follows

$\eta_{H}=\frac{P_{M}}{P_{h}}=\frac{P_{M}}{\rho g Q H}$

where $P_{h}$ is the power potential of water. By using the velocity triangle, the theoretical hydraulic efficiency is as follows [27]

$\eta_{H}=2 C_{d}^{2}\left(\varphi \cos \alpha_{1}-\varphi^{2}+\frac{k \varphi \sin \alpha_{1} \cos \beta_{2}}{\sin \beta_{1}}\right)$

where $k$ is the coefficient of friction in the bucket with a value between 0.90 and 0.95 .

\section{Coconut Shell Spoon Bucket}

Coconut shells are natural materials that are easily obtained and widely used as household furniture in Indonesia. They are also used as vegetable spoons (Figure 3). The use of the hereditary coconut shell material indicates that this material is extremely resistant to water. The coconut shells spoon in Figure 3 is sold in Indonesia both in cities and villages.

Prior to the application of a coconut shell material for the bucket of the Turgo turbine, it is crucial to perform geometrical analysis. Geometrical analysis is performed to estimate the change in momentum that occurs due to changes in the jet direction. The changes in the jet direction are caused by the curvature of the spoon. In addition, the strength of the coconut shell spoon material needs to be estimated as it will come in contact will pressurized water. The strength is estimated to determine the limit of water pressure that the bucket can withstand. 


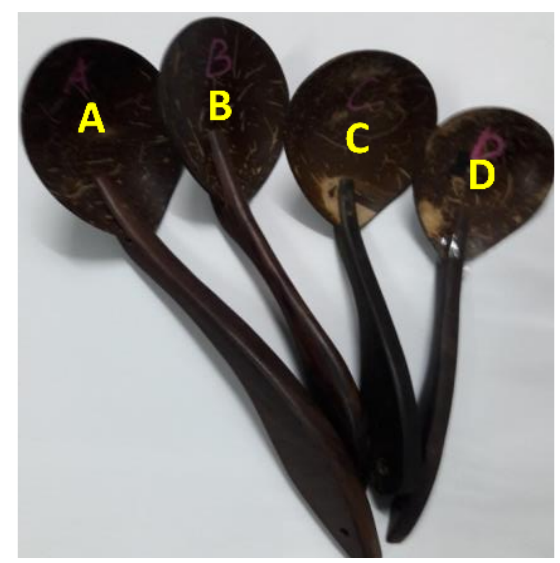

Fig. 3. Shape of the coconut shell spoon from the Indonesian market

\subsection{Geometry of Coconut Shell Spoon}

The geometrical analysis of the coconut shell spoon is carried out to determine the shape of the spoon (Figure 3) that can absorb the highest amount of water energy. Geometrical analysis is performed by the measurement of the length $(L)$, width $(B)$, depth $(T)$, and angle of curvature (Figures 4 and 5, and Table 1).

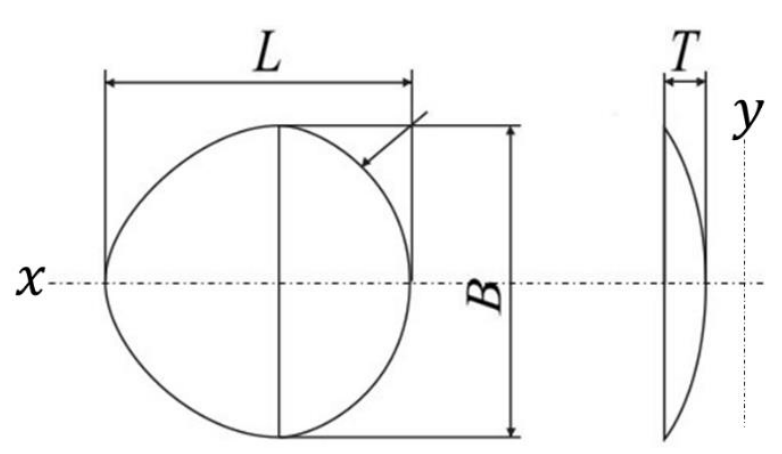

(a)

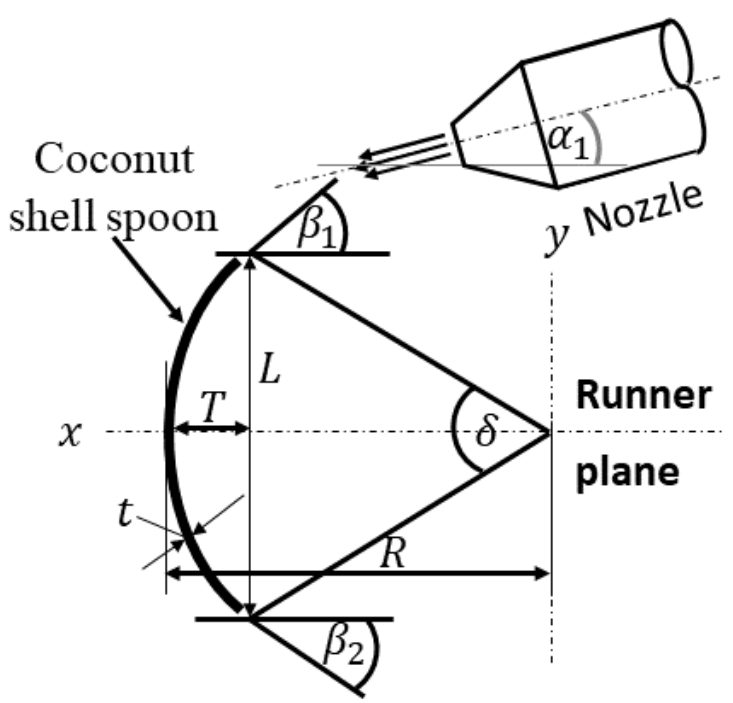

(b)

Fig. 4. Geometry of the spoon (a) Transverse dispay of the spoon (b) Dimension of the spoon

Table 1

Dimensions of the coconut shell spoon from the Indonesian market

\begin{tabular}{lllllll}
\hline Type & $L(\mathrm{~mm})$ & $T(\mathrm{~mm})$ & $R(\mathrm{~mm})$ & $B(\mathrm{~mm})$ & $t(\mathrm{~mm})$ & $\delta\left(^{\circ}\right)$ \\
\hline Spoon A & 95 & 20 & 66 & 8.0 & 1.5 & 92 \\
Spoon B & 90 & 12 & 90 & 7.5 & 1.5 & 60 \\
Spoon C & 85 & 10 & 95 & 7.5 & 1.5 & 53 \\
Spoon D & 80 & 11 & 78 & 6.2 & 1.5 & 62 \\
\hline
\end{tabular}




\subsection{Geometrical Positions of the Coconut Shell Spoons towards the Runner Plane}

If $\alpha_{1}$ and $\varphi$ are fixed, then $\beta_{1}$ will not change (Eq. 3). However, $\eta_{H}$ will change because of changes in $\beta_{2}$ (Eq. 7). $\beta_{2}$ depends on the position of the blade towards the plane parallel to the axis. Geometrical analysis is performed by positioning the four spoon models (i.e., A, B, C and D, respectively) with the same $\alpha_{1}$ value. The $\alpha_{1}$ values are varied in the range of $10^{\circ}, 20^{\circ}, 30^{\circ}$, and $40^{\circ}$. Although the $\alpha_{1}$ value for all four spoons are the same, the $\beta_{2}$ value will vary. By rotating the blade (changing the blade position) towards the runner plane until the desired $\alpha_{1}$ value is obtained, $\beta_{1}$ and $\beta_{2}$ can be determined using the analysis shown in Figure 5 and Eq. (3), (8) and (9). Thus, $\eta_{H}$ for each bucket or spoons model can be determined using Eq. (7).

$\delta=2 \arcsin \frac{L}{2 R}$

$\beta_{2}=180^{\circ}-\delta-\beta_{1}$

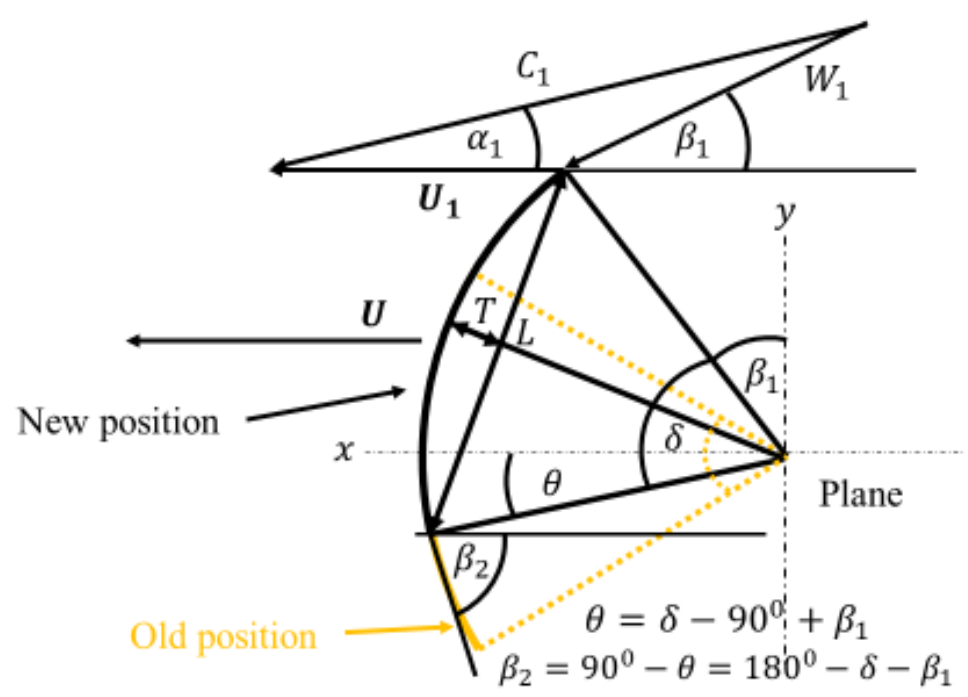

Fig. 5. Concept of the vector velocity triangle analysis on coconut shell spoons

\section{Static Test Pressure of the Coconut Shell Spoon}

The strength of the coconut shell spoon is estimated by static compressive strength tests to determine the maximum static load that it can withstand until it undergoes cracks or breakage. This test is carried out using Marshall's test equipment and the Marshall test (Figure 6a).

The strength test is carried out using 30 samples comprising models $A(0)$ and $C$. The spoon sample is pressed using a steel ball (pounder) (Figure 6b). The surface of the sample that meets the steel ball is measured using Vernier callipers. The deformation depth is measured using a dial gauge $(\mu \mathrm{m})$. The measured depth values are converted to force, which is first multiplied by a calibration factor of $0.3979 \mathrm{kgf} / \mathrm{div}$. Then, to calculate the total force that can damage the coconut shell spoon, the results from the calibration product are converted into Newton $(\mathrm{N})$, with a conversion of $1 \mathrm{kgf} \approx 9.81 \mathrm{~N}$, and added to $7.3637 \mathrm{~N}$. The value of $7.363 \mathrm{~N}$ is the total weights of the steel ball, nuts and bolt. Furthermore, the surface pressure of the sample is determined by dividing the total force that can damage the sample with the surface area of the sample that meets the steel ball. Figure 7 shows the results obtained from the static compressive strength tests using the Marshall test. The static 
compressive strength of the coconut shell spoon affords a large standard deviation, with an uncertainty percentage of greater than $20 \%$ (Figure 7). Such a high uncertainty value is related to the different thicknesses of the sample. The average static compressive strengths of model $A$ and $C$ spoons are $19.023 \pm 3,9 \mathrm{MPa}$ and 19,104 $\pm 5,1 \mathrm{MPa}$, respectively.

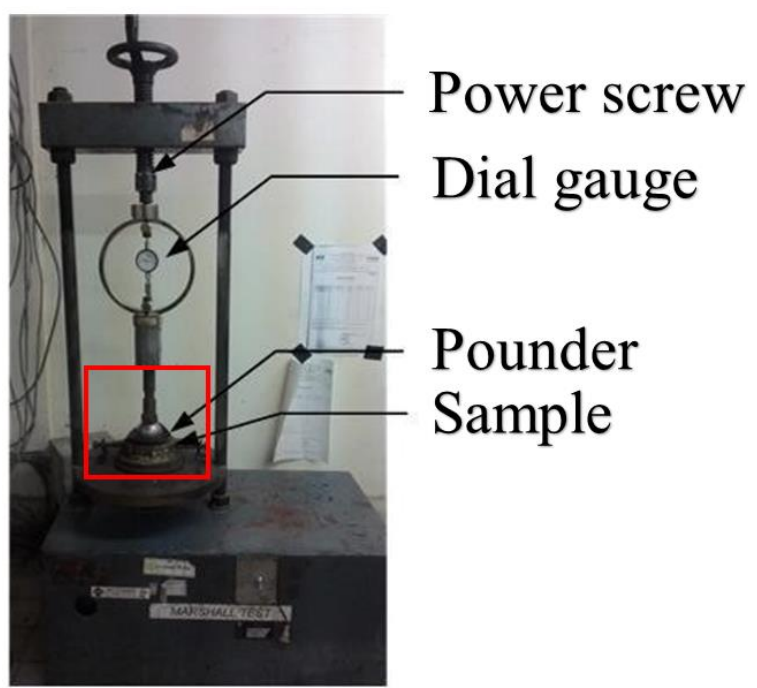

(a)

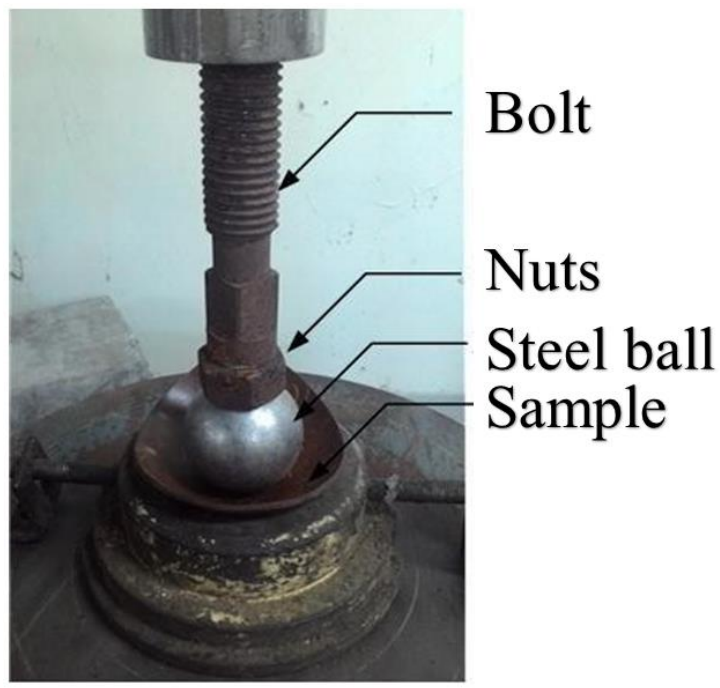

(b)

Fig. 6. Marshall text method (a) Static pressure test equipment (b) Sample testing

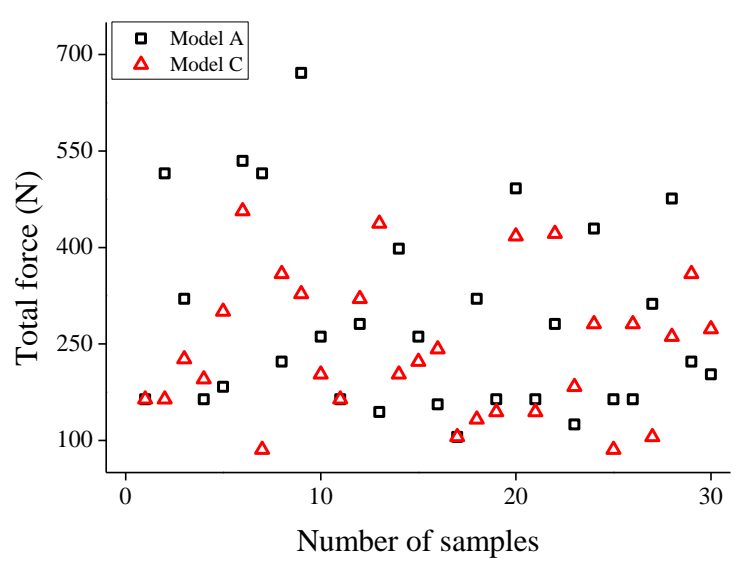

(a)

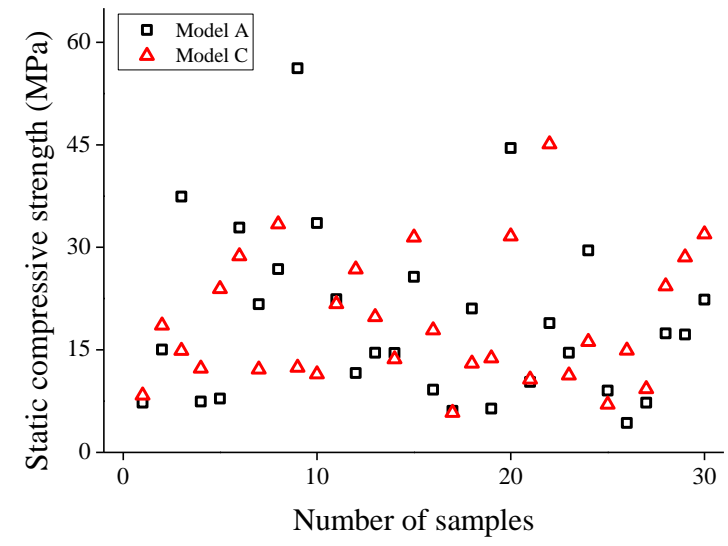

(b)

Fig. 7. Static compressive strength test results (a) Total force (b) Static compressive strength

If the Turgo turbine exhibits a capacity of 500-2500 W with an efficiency of $45-55 \%$, then the maximum force of water to the bucket can be determined as follows. Based on the Euler concept in Eq. 5, the maximum efficiency can be attained if $C_{x 2}$ is assumed to be 0 . Furthermore, the power produced by the turbine $\left(P_{M}\right)$ is calculated using Eq. 10

$P_{M}=\tau \cdot \omega$

where $\tau$ is the torque, and $\omega$ is the rotational speed of the wheel. $\tau$ is determined using Eq. (9)

$\tau=\rho \cdot Q\left(r_{1} C_{x 1}-r_{2} C_{x 2}\right)$ 
where $r$ is the radius of the wheel. Hence, the force of water to the bucket is expressed by $\rho \cdot Q \cdot C_{x 1}$ or

$F=p_{j e t} \cdot A$

where $p_{j e t}$ is the pressure of the jet, and $A$ is the bucket area. The determination of $A$ is adapted from the circle area equation; hence, $A=\pi \cdot d^{2} / 4 . d$ is the nozzle diameter, which is equal to $\mathrm{L} /(2$ until 3) or $\mathrm{T} \cdot(0.8$ until 1.2). Hence, $d$ for the bucket model $\mathrm{A}$ is $0.032 \mathrm{~m}$. Table 2 summarizes the calculation using Eq. 12.

Table 2

Analysis of the pressure received by the bucket at a potential power of $1100-3300 \mathrm{~W}$

\begin{tabular}{llllll}
\hline$P_{h}(\mathrm{~W})$ & $\eta_{H}(\%)$ & $P_{u}(\mathrm{~W})$ & $Q\left(\mathrm{~m}^{3} / \mathrm{s}\right)$ & $\mathrm{F}(\mathrm{N})$ & $p_{\text {jet }}(\mathrm{MPa})$ \\
\hline 1100 & 45 & 495 & 0.056 & 342.00 & 0.42 \\
1700 & 45 & 765 & 0.087 & 528.54 & 0.66 \\
2200 & 45 & 990 & 0.112 & 684.00 & 0.85 \\
2750 & 45 & 1238 & 0.140 & 854.99 & 1,06 \\
3300 & 45 & 1485 & 0.168 & 1025.99 & 1,28 \\
\hline
\end{tabular}

Based on Table 2, for a $P_{h}$ of $3300 \mathrm{~W}, p_{j e t}$ is $1.28 \mathrm{MPa}$. On the other hand, the bucket model A can withstand loads up to $19.023 \pm 3,9 \mathrm{MPa}$. Thus, coconut shells can be used as the bucket for the pico-scale Turgo turbine.

\section{Calculation Results}

Eq. 7 is utilized to determine the $\eta_{H}$ values for each spoon model, where $\alpha_{1}$ is varied from $10^{\circ}$ to $40^{\circ}$ [28], $C_{d}$ is set at $0.97, k$ is set at 0.92 [24], and the optimum $\varphi$ value depends on the $\alpha_{1}$ value (See Table 3 for more details) [28].

Table 4 summarizes the results obtained from the calculations using Eq. 7. Based on Table 4, spoon type $A$ is the good choice as a blade because it has a higher efficiency than other types. Thus, type $A$ is used as a blade (see Figure 8 ).

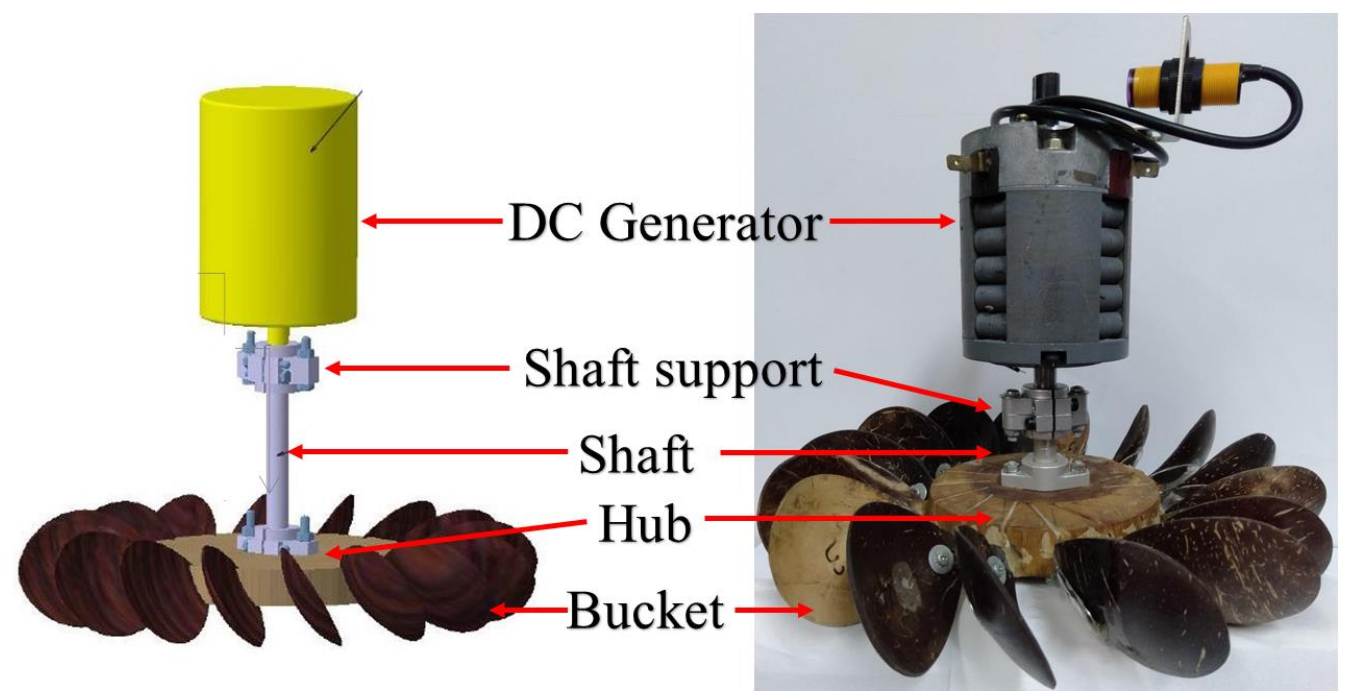

(a)

(b)

Fig. 8. Turgo turbine (a) Schematic of the Turgo turbine (b) Top-view of runners 
Table 3

Relationship of $\varphi$ and $\alpha_{1}$

\begin{tabular}{|c|c|c|c|c|}
\hline Para & Value & & & \\
\hline$\alpha_{1}$ & $10^{\circ}$ & $20^{\circ}$ & $30^{\circ}$ & $40^{\circ}$ \\
\hline$\varphi$ optimum & 0.62 & 0.58 & 0.53 & 0.52 \\
\hline
\end{tabular}

Table 4

Effect of $\alpha_{1}$ on $\eta_{H}$ based on analytical calculation

\begin{tabular}{lllllllllll}
\hline Spoon model & $L(\mathrm{~mm})$ & $T(\mathrm{~mm})$ & $R(\mathrm{~mm})$ & $T / L$ & $\varphi$ & $\delta\left(^{\circ}\right)$ & $\alpha_{1}\left(^{\circ}\right)$ & $\beta_{1}\left({ }^{\circ}\right)$ & $\beta_{2}\left({ }^{\circ}\right)$ & $\eta_{H}(\%)$ \\
\hline A & 95 & 20 & 66 & 0.21 & 0.62 & 92 & 10 & 25 & 63 & 62 \\
B & 90 & 12 & 90 & 0.13 & 0.62 & 60 & 10 & 25 & 95 & 38 \\
C & 85 & 10 & 95 & 0.12 & 0.62 & 53 & 10 & 25 & 102 & 33 \\
D & 80 & 11 & 78 & 0.14 & 0.62 & 62 & 10 & 25 & 93 & 49 \\
A & 95 & 20 & 66 & 0.21 & 0.58 & 92 & 20 & 44 & 44 & 73 \\
B & 90 & 12 & 90 & 0.13 & 0.58 & 60 & 20 & 44 & 76 & 49 \\
C & 85 & 10 & 95 & 0.12 & 0.58 & 53 & 20 & 44 & 83 & 43 \\
D & 80 & 11 & 78 & 0.14 & 0.58 & 62 & 20 & 44 & 74 & 51 \\
A & 95 & 20 & 66 & 0.21 & 0.55 & 92 & 30 & 58 & 30 & 81 \\
B & 90 & 12 & 90 & 0.13 & 0.55 & 60 & 30 & 58 & 62 & 59 \\
C & 85 & 10 & 95 & 0.12 & 0.55 & 53 & 30 & 58 & 69 & 53 \\
D & 80 & 11 & 78 & 0.14 & 0.55 & 62 & 30 & 58 & 60 & 60 \\
A & 95 & 20 & 66 & 0.21 & 0.53 & 92 & 40 & 70 & 18 & 85 \\
B & 90 & 12 & 90 & 0.13 & 0.53 & 60 & 40 & 70 & 50 & 67 \\
C & 85 & 10 & 95 & 0.12 & 0.53 & 53 & 40 & 70 & 57 & 61 \\
D & 80 & 11 & 78 & 0.14 & 0.53 & 62 & 40 & 70 & 48 & 68 \\
\hline
\end{tabular}

\section{Manufacturing of Turgo Turbine Runners}

During the manufacturing process of the Turgo turbine runner, a readymade material is possibly used to reduce manufacturing costs. However, wood and stainless-steel spoons must be processed first. The wood must be formed in a circle, which will be used as a hub that functions as a stainlesssteel spoon holder, and the stainless-steel spoon handle must be cut and used as a connector between the coconut shell spoon and hub. Then, the bucket (coconut shell spoon) is placed into the formed hub gap (Figure 8).

\section{Experimental Method}

As the Turgo turbine will be used in remote areas, the used measuring instruments must be costeffective, albeit exhibit a good accuracy and low uncertainty [29]. A micro-controller with a capacity of 8 bits is used with three sensors: A DC current and voltage measuring device, flow measuring device, and rotational speed device.

The DC current and voltage measuring device uses an INA129 sensor with an operational range of 0-26 Vdc. The flow measuring device uses the YF-DN40 sensor with an operational range of 0-150 $\mathrm{Ipm}$. The rotational speed device uses the proximity E18-D80NK sensor. All measuring instruments are built and verified using commercial measuring instruments. The DC current and voltage measuring device and the rotational speed device are verified using a commercial measuring device, while the flow measuring device is verified using a measuring cup and rotameter. Based on the verification results, the percentage of accuracy for the built measuring instruments is divided into two categories: full scale and reading. The full scale for the current DC measuring devices exhibits an accuracy of $0.8 \%$ and a DC voltage of $4.5 \%$ [29]. The reading for rotational speed measuring devices 
exhibits an accuracy of $\pm 2.74 \mathrm{rpm}$ and a flow rate of $\pm 0.76 \mathrm{lpm}$ [29]. Figure 9 shows the experimental setup.

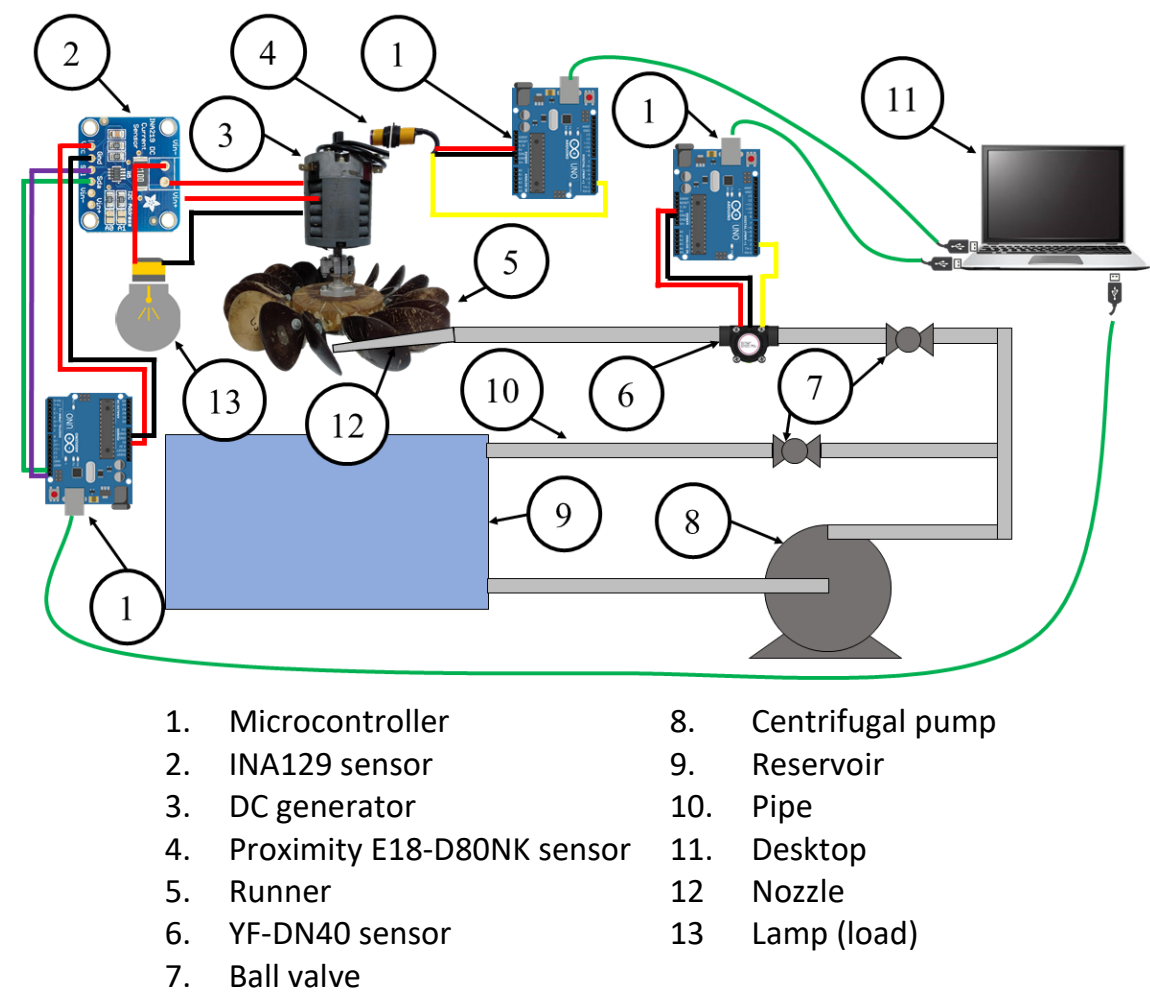

Fig. 9. Experimental setup

The electric power $\left(P_{e}\right)$ produced by the turbine is estimated by the following Eq. 13

$P_{e}=v \cdot i$

where $v$ is the DC voltage, and $i$ is the DC current. Hence, the total efficiency can be determined using Eq. 14

$\eta_{t}=\frac{P_{e}}{P_{h}}$

\section{Experimental Results}

Tests are carried out using a lamp with a load of $12 \mathrm{Vdc}$ and with five sizes for the nozzle diameter (d): $19 \mathrm{~mm}, 16 \mathrm{~mm}, 15 \mathrm{~mm}, 10 \mathrm{~mm}$, and $8 \mathrm{~mm}$. The nozzle size is varied to estimate the appropriate $\mathrm{D} / \mathrm{d}$ ratio in the pico-scale Turgo turbine. Figure 10 shows the test results. Based on Figure 10, the size of the nozzle affects the performance of the Turgo turbine, where a D/d ratio of $22(d=19 \mathrm{~mm})$ affords a higher total efficiency than those of the others, with the peak of the total efficiency observed at $34.94 \%$ at a rotation speed of $404.25 \mathrm{rpm}$. Based on the results, a D/d ratio of 22 is recommended for use in the pico-scale Turgo turbine.

Based on the measurement, there is a minimum flow required for the turbine to produce electrical power: For a $D / d$ ratio of 11.6 , the minimum flow is $48 \pm 0.05 \mathrm{lpm}$, for a $\mathrm{D} / \mathrm{d}$ ratio of 13.7, it is $33.52 \pm 0.16 \mathrm{lpm}$, for a $\mathrm{D} / \mathrm{d}$ ratio of 14.67 , it is $31.7 \pm 0.14 \mathrm{lpm}$, for a $\mathrm{D} / \mathrm{d}$ ratio of 22 , it is $19.17 \pm$ 
$0.18 \mathrm{lpm}$, and for a D/d ratio of 27.5 , it is $15.06 \pm 0.01 \mathrm{lpm}$ because the used DC generator will generate current $(i)$ if the minimum rotational speed is $190 \mathrm{rpm}$ (Figure 10).

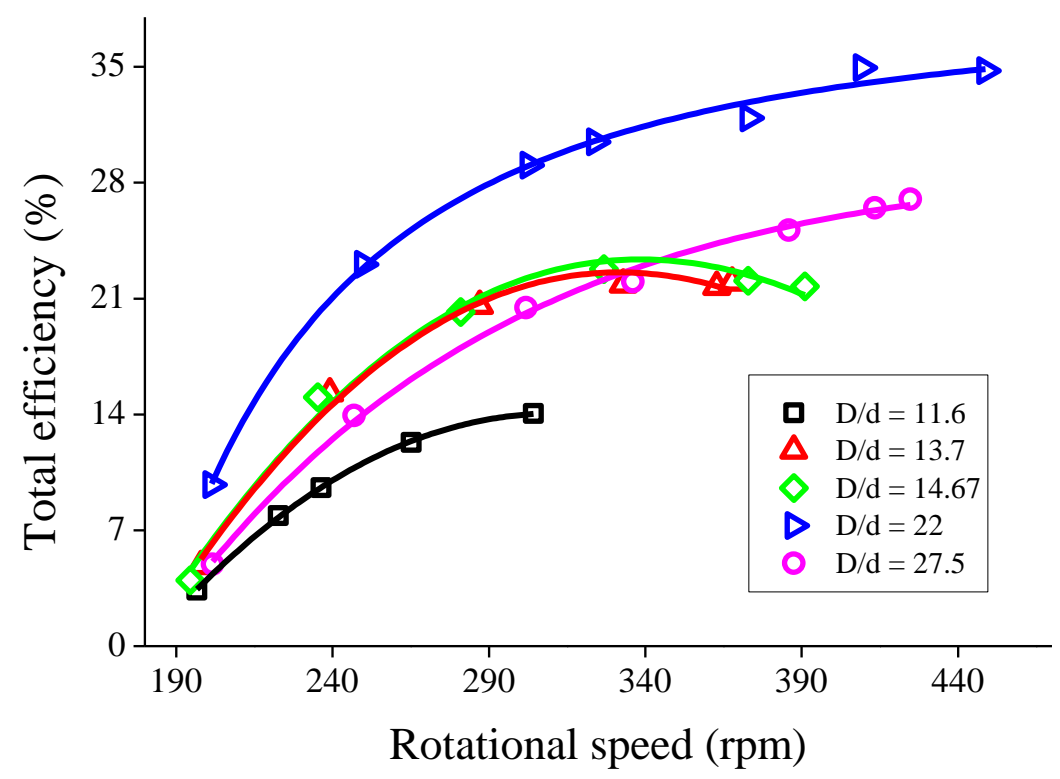

Fig. 10. Experimental results

\section{Discussion}

This study is a follow-up study conducted by Budiarso et al., [16], and it verifies the study conducted by Gaiser et al., [23]. The Turgo turbine designed by Budiarso et al., [16] exhibits a hydraulic efficiency of $44.3 \%$ and an investment cost of USD 48 . On the other hand, the turbine designed by Gaiser et al., [23] exhibits a hydraulic efficiency of $63.4 \%$ and an investment cost only of USD 30. However, the reliability of the Turgo turbines designed by Budiarso et al., [16] and Geiser et al., [23] for applications is still doubtful because the reported efficiency is the hydraulic efficiency and not the total efficiency (electrical power). To clarify this doubt, the design of the runner dimension utilizes the boundary conditions proposed by Gaiser et al., [23], with the only difference being the bucket material, and this turbine is connected to the DC generator. Hence, the boundary conditions proposed by Gaiser et al., [23] are appropriate for use in the design of a pico-scale Turgo turbine. Moreover, the investment cost required to manufacture a Turgo turbine using coconut shell material is USD 29, which is more cost-effective than those reported by Budiarso et al., [16] and Gaiser et al., [23] (see Table 5). This price does not include all of the cost, if the including the DC generator and piping system the total price for manufacture is USD 85. Furthermore, if it is assumed the effiency of the DC generator used is $60 \%$, then the mechanical efficiency of the tubrine that builds is $58.3 \%$ (35\% devided 60\%).

Table 5

Comparison investment cost and efficiency this study with previous studies

\begin{tabular}{llll}
\hline Authors & Price & Efficiency Mechanics & Total Efficiency \\
\hline Budiarso et al., [16] & USD 48 & $44.3 \%$ & - \\
Gaiser et al., [23] & USD 30 & $63.4 \%$ & - \\
This study & USD 29 & $58.3 \%$ & $35 \%$ \\
\hline
\end{tabular}


There is a significant difference in the $D / d$ ratio for maximum operational conditions, where Gaiser et al., [23] have recommended an optimum D/d ratio from 6.99 to 18.25 . On the other hand, the results obtained herein are similar to the recommendations reported in the study by Cobb et al., [30]. The results obtained herein and those reported by Cobb et al., [30] are presumably correct because the total efficiency is reported; hence, the minimum rotation required to produce power is also accumulated. Thus, based on previous study [30], it can be said that the test carried out is valid and verified.

\section{Conclusions}

The theoretical hydraulic efficiency of the Turgo turbine is the maximum due to the large ratio between the depth and length of the spoon ( $T / L$ ratio) and the absolute angle of the incoming jet $\left(\alpha_{1}\right)$. The depth and length of the spoon affect the magnitude of the angle of the relative incoming $\left(\beta_{1}\right)$ and outgoing jets $\left(\beta_{2}\right)$. $\beta_{1}$ and $\beta_{2}$ represent the curvature angles of the coconut shell spoon $(\delta)$, and a $\delta \approx 90^{\circ}$ is required to achieve a high hydraulic efficiency.

Coconut shells can be used as the Turgo turbine bucket material because the pressure received by the blade with a potential power of $3300 \mathrm{~W}$ is less than the maximum pressure that the coconut shell can withstand. Based on the results, the total efficiency of the turbine is $34.94 \%$, with a possibility of achieving higher values if tested with a head above $5 \mathrm{~m}$.

To increase the level of technological readiness, the as-built Turgo turbine will be tested under actual conditions to investigate the issues experienced by the turbine under real conditions.

\section{Acknowledgement}

This work supported by the Directorate of Research and Service Community (DRPM) Universitas Indonesia with grant No: NKB-0156/UN2.R3.1/HKP.05.00/2019.

\section{References}

[1] Direktorat Jenderal Ketenagalistrikan. "Update Informasi (Sub Sektor Ketenagalistrikan)." Jakarta, 2019.

[2] Budiarso B., Adanta, Dendy, Dwi Jaya, Hardika Widi Satria, and Arius Krypton Onarelly. "Metode penerapan piko hidro sebagai pembangkit listrik mandiri dalam komunikasi pembangunan bagi masyarakat di dareah terpencil." In SEMINAR NASIONAL PENGABDIAN MASYARAKAT PERGURUAN TINGGI 2017. 2017.

[3] F. M. Sari. "PLN Kembangkan Pembangkit Listrik Tenaga Piko Hidro di Papua." Jakarta, 2019.

[4] S. K. Yudha. "PLN Gunakan Piko Hidro Terangi Desa di Papua." Jakarta, 2019.

[5] Direktorat Jenderal Ketenagalistrikan Kementerian Energi dan Sumber Daya Minerl. "Statistik Ketenagalistrikan TA 2017." 2018.

[6] Zainuddin, H., M. S. Yahaya, J. M. Lazi, M. F. M. Basar, and Z. Ibrahim. "Design and development of pico-hydro generation system for energy storage using consuming water distributed to houses." World Academy of Science, Engineering and Technology 59, no. 1 (2009): 154-159.

https://doi.org/10.1109/ICDRET.2009.5454216

[7] Ho-Yan, Bryan. "Design of a low head pico hydro turbine for rural electrification in Cameroon." PhD diss., 2012.

[8] Adanta, Dendy, Warjito Budiarso, and Ahmad Indra Siswantara. "Assessment of turbulence modelling for numerical simulations into pico hydro turbine." Journal of Advanced Research in Fluid Mechanics and Thermal Sciences 46, no. 1 (2018): 21-31.

[9] Maher, P., N. P. A. Smith, and A. A. Williams. "Assessment of pico hydro as an option for off-grid electrification in Kenya." Renewable Energy 28, no. 9 (2003): 1357-1369.

https://doi.org/10.1016/S0960-1481(02)00216-1

[10] Adhikari, Pradhumna, Umesh Budhathoki, Shiva Raj Timilsina, Saurav Manandhar, and Tri Ratna Bajracharya. "A Study on Developing Pico Propeller Turbine for Low Head Micro Hydropower Plants in Nepal." Journal of the Institute of Engineering 9, no. 1 (2013): 36-53.

https://doi.org/10.3126/jie.v9i1.10669

[11] Vicente, Silvia, and Hans Bludszuweit. "Flexible design of a pico-hydropower system for Laos 
communities." Renewable energy 44 (2012): 406-413.

https://doi.org/10.1016/i.renene.2012.02.011

[12] Gladstone, Scott, Victoria Tersigni, Kevin Francfort, and Julie Ann Haldeman. "Implementing pico-hydropower sites in rural Rwanda." Procedia Engineering 78 (2014): 279-286.

https://doi.org/10.1016/i.proeng.2014.07.068

[13] Thomas, Brian. "Pico-Hydropower Franchising in Rural Honduras." International Journal for Service Learning in Engineering, Humanitarian Engineering and Social Entrepreneurship 6, no. 1 (2011): 46-63. https://doi.org/10.24908/ijsle.v6i1.3213

[14] Nimje, Akhilesh Arvin, and Gopal Dhanjode. "Pico-hydro-plant for small scale power generation in remote villages." IOSR Journal of Environmental Science, Toxicology and Food Technology 9, no. 1 (2015): 59-67.

[15] Williamson, S. J., B. H. Stark, and J. D. Booker. "Low head pico hydro turbine selection using a multi-criteria analysis." Renewable Energy 61 (2014): 43-50. https://doi.org/10.1016/j.renene.2012.06.020

[16] Lubis, M. Naufal, and Dendy Adanta. "Performance of a low cost spoon-based turgo turbine for pico hydro installation." Energy Procedia 156 (2019): 447-451. https://doi.org/10.1016/j.egypro.2018.11.087

[17] Williamson, S. J., B. H. Stark, and J. D. Booker. "Performance of a low-head pico-hydro Turgo turbine." Applied Energy 102 (2013): 1114-1126. https://doi.org/10.1016/i.apenergy.2012.06.029

[18] Haidar, Ahmed MA, Mohd FM Senan, Abdulhakim Noman, and Taha Radman. "Utilization of pico hydro generation in domestic and commercial loads." Renewable and Sustainable energy reviews 16, no. 1 (2012): 518-524. https://doi.org/10.1016/i.rser.2011.08.017

[19] Harvey, Adam, and Allen Inversin. "Micro-Hydro Design Manual: A guide to small-scale water power schemes." In Natural Resources Forum, vol. 18, no. 1, p. 69. London: Butterworths., 1994. https://doi.org/10.3362/9781780445472.000

[20] Febriansyah, Dwijaya, Warjito Budiarso, Keizo Watanabe, and Dendy Adanta. "Storage System Manufacturability, Portability and Modularity for a Pico Hydro Turbine." Journal of Advanced Research in Fluid Mechanics and Thermal Sciences 51, no. 2 (2018): 209-214.

[21] Warjito, Budiarso, A. I. Siswantara, D. Adanta, M. Kamal, and R. Dianofitra. "Simple bucket curvature for designing a low-head Turgo turbine for pico hydro application." International Journal of Technology 8, no. 7 (2017): 12391247. https://doi.org/10.14716/ijtech.v8i7.767

[22] Aaraj, Youssef, Sorina Mortada, Denis Clodic, and Maroun Nemer. "Design Of A Turgo Two-Phase Turbine Runner." In INTERNATIONAL REFRIGERATION AND AIR CONDITIONING CONFERENCE. 2014.

[23] Gaiser, Kyle, Paul Erickson, Pieter Stroeve, and Jean-Pierre Delplanque. "An experimental investigation of design parameters for pico-hydro Turgo turbines using a response surface methodology." Renewable Energy 85 (2016): 406-418. https://doi.org/10.1016/j.renene.2015.06.049

[24] A. H. Gibson, Water Hammer in Hydraulic Pipe Lines. London: Archibald Constable and Co. Ltd., 1909.

[25] Anagnostopoulos, John S., and Dimitrios E. Papantonis. "Flow modeling and runner design optimization in Turgo water turbines." World Academy of Science, Engineering and Technology 28 (2007): 206-211.

[26] Harinaldi, Budiarso. "Sistem Fluida Prinsip Dasar dan penerapan Mesin Fluida, Sistem Hidrolik, dan Sistem Penumatik." Jakarta: Erlangga (2015).

[27] Massey, Bernard Stanford, and John Ward-Smith. Mechanics of fluids. Vol. 1. Crc Press, 1998.

[28] Gaiser, Kyle, Paul Erickson, Pieter Stroeve, and Jean-Pierre Delplanque. "An experimental investigation of design parameters for pico-hydro Turgo turbines using a response surface methodology." Renewable Energy 85 (2016): 406-418. https://doi.org/10.1016/i.renene.2015.06.049

[29] Adanta, Dendy, and Dwijaya Febriansyah. "Simple micro controller measurement devices for pico hydro turbines." International Review of Mechanical Engineering 13, no. 8 (2019): 471-480. https://doi.org/10.15866/ireme.v13i8.17453

[30] Cobb, Bryan R. "Experimental study of impulse turbines and permanent magnet alternators for pico-hydropower generation." (2011). 